\title{
A Scale to Measure the Attitude of Farmers towards the Eco-Friendly Technologies in Vegetable Cultivation
}

\author{
R. Rajasree*, F. L. Sharma and S. S. Sisodia \\ Department of Extension Education, Rajasthan College of Agriculture, Udaipur, India \\ *Corresponding author
}

\section{A B S T R A C T}

\section{Keywords}

Food quality, Food protection, Ecofriendly agriculture, Biodynamic agriculture, Organic farming

Article Info

Accepted:

07 November 2019

Available Online:

10 December 2019
Udaipur district of Rajasthan state has been identified as one of the district for promoting organic farming. With this context, the present study has been carried out in Udaipur to know the attitude of vegetable growers towards eco-friendly technologies in vegetable cultivation. For measuring attitude, a scale was developed in Likert method with 32 statements. 16 positive and 16 negative attitude statements were selected from different areas of eco-friendly technologies and framed. The statements were pretested and selected based on the ' $t$ ' values from the item analysis. The attitude scale may be useful for policy makers and researchers working in the field of eco-friendly management in crops.

\section{Introduction}

Vegetable farming is gaining importance from day by day. It is indispensable requirement to meet nutrients and mineral needs of the human body. But adverse effects of contemporary agricultural practices not only on the farm but also on the wellbeing of all living things and thus on the environment have been well documented all over the world. The consumers are more concerned about the quality of the products they consume and food safety has become a vital demand. Food quality, food protection and hygiene has become strict in the society. Along with this, sustainability is also a major concern of scientific community and farming community. Such concerns paved the way to adopt various alternative farming techniques like zero budget farming, biodynamic agriculture, organic farming and eco-friendly agriculture.

In some of the literature, eco-friendly farming is distinguished as organic farming itself, whereas in some other literature, both are dealt differently. In organic farming complete avoidance of synthetic compound is recommended but in eco-friendly agriculture, utilization of ecological benevolent synthetic products are permitted. Eco-friendly farming 
technology considers a small life form in the soil to human health.

Understanding the importance of alternative faming approaches, National Planning Commission of India in 2000, declared organic farming as a thrust area. As per the records, India's rank in terms of World's Organic Agriculture land was ninth and in terms of total number of producers was first as per 2018 data (Source: FIBL \&IFOAM Year Book). Among the different states which adopted organic farming Madhya Pradesh was the largest producer followed by Maharashtra, Karnataka, Uttar Pradesh and Rajasthan.

In case of organic certification process also Madhya Pradesh bagged first, since it has covered largest area in organic certification followed by Rajasthan, Maharashtra and Uttar Pradesh. In 2016, Government of Rajasthan selected Udaipur as one of the district among eleven districts were organic farming will be done. This has been done to improve the status of organic farming in the state by encouraging more farmers to adopt organic practices in their farmsteads.

One of the main reason for low adoption of eco-friendly management practices is that attitude possessed by the farmers. Prior research studies have found negative feelings towards alternative farming techniques existing in among the farming community. The studies conducted by the Assis and Ismail (2011), Kotresha et al., (2014), Mondal et al., (2014) and Roy et al., (2017) have mentioned that attitude of farmers were not satisfactory with regard to organic farming practices.

Looking into the above facts, it was quiet important to know the attitude of the farmers towards eco-friendly technologies in vegetable cultivation. The domains were categorized for developing scale was based on the previous studies and expert consultations.

\section{Materials and Methods}

Attitude is an organized predisposition to think, feel, perceive and behave towards a referent or cognitive object (Kerlinger, 1995). Attitude in the present study is defined as "the degree of positive or negative feeling, opinion, belief and action associated with eco-friendly technologies in vegetable cultivation by the farmers of Udaipur district" in which attitude of people can differ in varying degrees. For measuring this feeling, a scale has been developed. For constructing attitude scale, there are several techniques like summatedrating scales, equal appearing scales and cumulative scales. While looking into the requirements of the study, Likert's summated rating scale was selected as it requires less number of items and judges to start with. Comparatively it requires less time than the other techniques. It is a scale construction technique in which statements which can clearly distinguish favourable or unfavorable response of the individual about a particular object (Likert, 1932). The steps followed for scale construction are as follows Item collection from literature, relevancy tests, selection of items, Item analysis, Reliability test and Validity Test. Relevant statistical tools and techniques such as mean, median, variance and t-test was used for item analysis. The critical ratio ( $t$-value) for each item was worked out by the formula given by Edwards (1957) as follows:

$$
\mathrm{t}=\frac{\overline{\mathrm{X}}_{\mathrm{H}}-\overline{\mathrm{X}}_{\mathrm{L}}}{\sqrt{\frac{\Sigma\left(\mathrm{X}_{\mathrm{H}}-\overline{\mathrm{X}}_{\mathrm{H}}\right)^{2}+\Sigma\left(\mathrm{X}_{\mathrm{L}}-\overline{\mathrm{X}}_{\mathrm{L}}\right)^{2}}{\mathrm{n}(\mathrm{n}-1)}}}
$$

$\overline{\mathrm{X}}_{\mathrm{H}}=$ the mean score on a given statement for the high group

$\overline{\mathrm{X}}_{\mathrm{L}}=$ the mean score on a given statement for the low group 
$\mathrm{n}=$ Number of subjects on the upper and low group

$\mathrm{X}_{\mathrm{H}}=$ Score for a given statement in the high group

$\mathrm{X}_{\mathrm{L}}=$ Score for a given statement in the low group

\section{Results and Discussion}

\section{Collection of items}

The initial step was to collect as many statements related with the eco-friendly technologies in vegetable cultivation. Hence, items were collected based on the review of literature, discussions with experts and informal interviews with the vegetable growers. A tentative list of 52 statements was drafted keeping in view the applicability of statement to the area of study. Domains were mainly of Integrated Nutrient Management, Integrated Pest Management, Integrated Cropping Management, Economic benefits and Social factors.

\section{Editing of items}

The statements were carefully edited based on the criteria given by Likert (1932) and Edwards (1957). Ambiguous, irrelevant and statements not conforming to the suggested criteria were deleted. At this stage, statements were reduced to 40 .

Again the statements were rewritten in the light of comments of experts and arranged in positive and negative statements, alternatively. Hence, after editing 40 statements were retained for the study.

\section{Selection of items}

The statements were selected in such a way that they expressed the positive or negative attitude. In order to get a five point continuum, five alternative response category ranging from strongly agree to strongly disagree were assigned to each statement.

\section{Item analysis}

For item analysis, the items were first administered to a random sample of 60 farmers of the study area. The responses from then were elicited on a five point continuum viz. Strongly agree (SA), Agree (A), Undecided (UD), Disagree (DA) and Strongly disagree (SDA). The numerical values assigned for each was 5,4,3,2 and 1 respectively for positive statements and vice versa for negative statements. The score for each individual on the scale was computed by summing the response of individuals' item response.

Considering the total score obtained by each individual, these were arranged in the descending order. Then 25 per cent of the subjects with the highest total score and also 25 per cent of the subjects with the lowest total score were selected. These two groups provided the criterion groups as "high" and "low" groups to evaluate the individual item. The critical ratio (t-value) for each item was worked out (Table 1).

\section{Final selection of items}

The items having ' $\mathrm{t}$ ' value greater than 1.75 and equal to 1.75 were selected for the final format of the scale. By this procedure, 32 items retained and included in final format of attitude scale.

\section{Reliability of test}

The final format of 32 statements was split into two halves on the basis of odd and even number of items and it was administered to 15 randomly selected farmers. 
The responses were rated on five point continuum viz. Strongly agree, Agree, Undecided, Disagree and Strongly disagree having scores 5,4,3,2 and 1, respectively. Two sets of scores were obtained and these scores were correlated with each other. The correlation coefficient for two sets of scores was 0.85 . Thus, the product moment correlation coefficient produces reliability coefficient of the test. The correction factor was applied to get the full reliability of the test.

\section{Validity of the scale}

Validity of an instrument refers to how well it measures what it is to be measured. It is an important thing in the descriptive research. There are three types of validity; criterion validity, content validity and construct validity.

To test the validity of the scale, content validity of the attitude scale was done. Content validity is basically a judgmental where items of the test are being studied and each item being weighed for its presumed representativeness of the universe (Kerlinger, 1995). Content validity was assessed by asking 20 experts from various disciplines working in MPUAT. After the discussion with the panel, the questionnaire was reviewed and changes were made in line with the suggestions (Table 2).

Table.1 Attitude statements of item analysis with ' $t$ ' values

\begin{tabular}{|c|l|c|}
\hline S. No. & \multicolumn{1}{|c|}{ Statements } & $\begin{array}{c}\text { 't' value } \\
\text { (critical ratio) }\end{array}$ \\
\hline $\mathbf{1 .}$ & Eco-friendly technologies ensures biodiversity & 4.17 \\
\hline $\mathbf{2 .}$ & EFT requires more time than conventional agriculture & 5.21 \\
\hline $\mathbf{3 .}$ & EFT reduces environmental pollution & 3.96 \\
\hline $\mathbf{4 .}$ & EFT demands more patience for vegetable cultivation & 9.58 \\
\hline $\mathbf{5 .}$ & Eco-friendly technologies provides better quality vegetables & 2.75 \\
\hline $\mathbf{6 .}$ & EFT is efficient in mitigating climate change effects \\
\hline $\mathbf{7 .}$ & $\begin{array}{l}\text { In long term run, Eco-friendly technologies are better than any } \\
\text { conventional agricultural system. }\end{array}$ & 1.96 \\
\hline $\mathbf{8 .}$ & $\begin{array}{l}\text { Agricultural professionals posses proper knowledge about EFT in } \\
\text { vegetable cultivation }\end{array}$ & 4.56 \\
\hline $\mathbf{9 .}$ & EFT in vegetable cultivation is very easy to adopt by the farmers \\
\hline $\mathbf{1 0 .}$ & $\begin{array}{l}\text { EFT is transitionally difficult to sustain the livelihood of the } \\
\text { vegetable growers }\end{array}$ & 3.94 \\
\hline $\mathbf{1 1 .}$ & EFT provides social compatibility & 3.15 \\
\hline $\mathbf{1 2}$ & $\begin{array}{l}\text { Timely application of fertilizers positively affect the crop growth } \\
\text { and condition of the soils }\end{array}$ & 2.32 \\
\hline $\mathbf{1 3 .}$ & EFT won't give much production than inorganic cultivation \\
\hline $\mathbf{1 4 .}$ & Eco-friendly technologies improves soil structure and fertility & 3.02 \\
\hline $\mathbf{1 5}$ & $\begin{array}{l}\text { Products obtained through the application of EFT are beautiful in } \\
\text { appearance. }\end{array}$ & 1.82 \\
\hline $\mathbf{1 6 .}$ & Vegetables produced through the application of EFT has poor taste & 4.89 \\
\hline $\mathbf{1 7 .}$ & EFT reduces input costs of vegetable production & 1.76 \\
\hline & & 1.45 \\
\hline
\end{tabular}




\begin{tabular}{|c|c|c|}
\hline 18. & Package of practices about EFT is lacking in current scenario & 4.98 \\
\hline 19. & EFT strengthen the use of indigenous knowledge among the farmers & 3.69 \\
\hline 20. & $\begin{array}{l}\text { Proper demarcation from eco-friendly to conventional agriculture } \\
\text { must be formulated. }\end{array}$ & 3.65 \\
\hline 21. & $\begin{array}{l}\text { Vegetables produced through eco-friendly technologies has higher } \\
\text { demand than conventionally produced ones }\end{array}$ & 2.75 \\
\hline 22. & $\begin{array}{l}\text { Consumers are not still aware of the advantages of eco-friendly } \\
\text { vegetables }\end{array}$ & 2.93 \\
\hline 23. & EFT reduces pests and disease infestation in vegetables & 3.65 \\
\hline 24. & EFT is difficult to manage by fellow farmers & 3.86 \\
\hline 25. & $\begin{array}{l}\text { Farmers can obtain optimum production if he possess livestock at } \\
\text { their farm }\end{array}$ & 3.98 \\
\hline 26. & $\begin{array}{l}\text { Premium price is not ensured for the vegetables produced through } \\
\text { eco-friendly technology }\end{array}$ & 3.15 \\
\hline 27. & $\begin{array}{l}\text { Profits are more important for the farmers than the environmental } \\
\text { issue }\end{array}$ & 1.50 \\
\hline 28. & Success and failures of farming lies in the hand of end users. & 1.25 \\
\hline 29. & $\begin{array}{l}\text { I have to face the problem in sourcing and purchasing of organic } \\
\text { inputs }\end{array}$ & 1.40 \\
\hline 30. & I feel young farmers should take up EFT in vegetable cultivation & 2.86 \\
\hline 31. & $\begin{array}{l}\text { Shifting from conventional agriculture to eco-friendly cultivation is } \\
\text { laborious }\end{array}$ & 3.94 \\
\hline 32. & $\begin{array}{l}\text { Eco-friendly technologies in vegetable cultivation does not offer } \\
\text { potential for food security }\end{array}$ & 4.17 \\
\hline 33. & $\begin{array}{l}\text { Application of green manure gives good results in vegetable } \\
\text { production }\end{array}$ & 1.15 \\
\hline 34. & $\begin{array}{l}\text { Use of pest and diseases resistant varieties will control pest and } \\
\text { disease attack in vegetables }\end{array}$ & 1.30 \\
\hline 35. & $\begin{array}{l}\text { Timely inter cultivation is most important to check weed, pest, } \\
\text { diseases, etc. }\end{array}$ & 3.15 \\
\hline 36. & $\begin{array}{l}\text { Timely weeding helps to provide required nutrients to vegetable } \\
\text { crops }\end{array}$ & 4.21 \\
\hline 37. & Use of neem cake to control nematode/ root disease & 3.52 \\
\hline 38. & $\begin{array}{l}\text { Application of crop residues in field can acts a invitation for new } \\
\text { pest }\end{array}$ & 3.94 \\
\hline 39. & $\begin{array}{l}\text { Alternate day irrigation saves water irrespective of crop water } \\
\text { requirement }\end{array}$ & 1.25 \\
\hline 40. & $\begin{array}{l}\text { Application of green manuring improves soil condition but it is } \\
\text { laborious and time consuming }\end{array}$ & 1.85 \\
\hline
\end{tabular}


Table.2 Attitude of respondents towards eco-friendly technologies (Final scale)

\begin{tabular}{|c|c|c|}
\hline S. No. & Statements & $\begin{array}{l}\text { Degree of } \\
\text { statement }\end{array}$ \\
\hline 1. & Eco-friendly technologies ensures biodiversity & + \\
\hline 2. & EFT requires less time than conventional agriculture & - \\
\hline 3. & EFT reduces environmental pollution & + \\
\hline 4. & EFT demands less patience for vegetable cultivation & - \\
\hline 5. & Eco-friendly technologies provides better quality vegetables & + \\
\hline 6. & EFT is not efficient in mitigating climate change effects & - \\
\hline 7. & EFT is transitionally difficult to sustain the livelihood of the vegetable growers & + \\
\hline 8. & $\begin{array}{l}\text { Agricultural professionals posses proper knowledge about EFT in vegetable } \\
\text { cultivation }\end{array}$ & - \\
\hline 9. & EFT provides social compatibility & + \\
\hline 10. & EFT in vegetable cultivation is very easy to adopt by the farmers & - \\
\hline 11. & EFT won't give much production than inorganic cultivation & + \\
\hline 12. & Eco-friendly technologies improves soil structure and fertility & - \\
\hline 13. & Vegetables produced through the application of EFT has good taste & + \\
\hline 14. & EFT reduces input costs of vegetable production & - \\
\hline 15. & Package of practices about EFT is lacking in current scenario & + \\
\hline 16. & EFT won't strengthen the use of indigenous knowledge among the farmers & - \\
\hline 17. & Proper demarcation from eco-friendly to conventional agriculture is known. & + \\
\hline 18. & $\begin{array}{l}\text { Vegetables produced through eco-friendly technologies has less demand than } \\
\text { conventionally produced ones }\end{array}$ & - \\
\hline 19. & $\begin{array}{c}\text { Majority of consumers are not still aware of the advantages of eco-friendly } \\
\text { vegetables }\end{array}$ & + \\
\hline 20. & EFT is difficult to manage by fellow farmers & - \\
\hline 21. & EFT reduces pests and disease infestation in vegetables & + \\
\hline 22. & $\begin{array}{l}\text { Premium price is not ensured for the vegetables produced through eco-friendly } \\
\text { technology }\end{array}$ & - \\
\hline 23. & Farmers can obtain optimum production if he possess livestock at their farm & + \\
\hline 24. & Shifting from conventional agriculture to eco-friendly cultivation is laborious & - \\
\hline 25. & Vegetables produced through EFT is good for normal health & + \\
\hline 26. & $\begin{array}{l}\text { Eco-friendly technologies in vegetable cultivation does not offer potential for } \\
\text { food security }\end{array}$ & - \\
\hline 27. & I feel young farmers should take up EFT in vegetable cultivation & + \\
\hline 28. & Use of neem cake cannot control nematode/ root disease & - \\
\hline 29. & Timely inter cultivation is most important to check weed, pest, diseases, etc. & + \\
\hline 30. & Application of green manure won't gives good results in vegetable production & - \\
\hline 31 & Application of crop residues in field can acts a invitation for new pest & + \\
\hline 32. & Timely weeding helps to provide required nutrients to vegetable crops & - \\
\hline
\end{tabular}

MPS= Mean Per cent Score 


\section{Administration of the scale}

The attitude scale was incorporated in the final format of the interview schedule for administration to the sampled farmers. The scale consists of 16 positive and 16 negative statements. The scale for administration was provided with five response categories viz. "Strongly agree, Agree, Undecided, Disagree and Strongly disagree" with scores 5, 4, 3, 2 and 1 for the positive statement and vice-versa for negative statement.

Scale developed will be useful to future researchers for measuring the attitude of farmers towards eco-friendly technologies. The scale contains various aspects of crop production, crop protection, economic aspects and psychological aspects. Equal number of positive and negative statements were selected and framed on the basis of expert opinions, literatures and after statistical analysis.

\section{References}

Assis, K. and Ismail Mohammad, H.A. 2011. Knowledge, attitude and practices of farmers towards organic farming. International Journal of Economic Research 2(3):1-6.

Edwards, L. (1957). Techniques of attitude scale construction, Appleton Century Craft Inc., New York.

Kerlinger, F.N. (1973). Foundation of Behavioural Research. New York. Holt. Rinehand and Hinston.

Kotresha, S. S. 2014. Farmer's attitude towards organic farming. Environment and Ecology 32(3): 825-828.

Likert, R. (1932). A technique for the measurement of attitudes. New York: The Science Press.

Mondal, S., Theerachai, H. and Simarkar, S. 2014. Farmer's knowledge, Attitude and Practice towards organic vegetable cultivation in North East Thailand. Kasetart Journal of Social Sciences 35:158-166.

Roy, U.K., Hossain, K.Z., Islam, M.R. and Rahman, M.S. 2017. Farmers' attitude towards Integrated Pest Management (IPM) practices in vegetable cultivation. Journal of Agriculture and Rural Research 1(2): 91-97.

\section{How to cite this article:}

Rajasree, R., F. L. Sharma and Sisodia, S. S. 2019. A Scale to Measure the Attitude of Farmers towards the Eco-Friendly Technologies in Vegetable Cultivation. Int.J.Curr.Microbiol.App.Sci. 8(12): 582-588. doi: https://doi.org/10.20546/ijcmas.2019.812.076 